\title{
81 preface to a selection of the celebration speeches
}

\author{
Nirmal Puwar
}

This section brings you the speeches delivered in celebration and reflection of 25 years of being $A$ journal and a collective at the Brunei Gallery on the evening of 17 June 2005. The panel respectively spoke of the past, present and future. It was Chaired by the longest serving member, Dot Griffiths, who has been with the Feminist Review Collective from the start. She has put down some of the thoughts that informed her impromptu charming and entertaining performance on paper. The first speaker was one of the founding members Elizabeth Wilson. She didn't have any notes that she could recall her speech from so unfortunately we have not been able to print her words. The second speaker was another past member, Gail Lewis. She left the journal in the early 1990s. She was ill on the night and therefore was not able to join us. However, we are able to read her speech on the past experiences of being in Feminist Review. And then two current members spoke. Amal Treacher deliberated on the present for us and I tried to gauge future possibilities, by asking - What kind of (academic) feminists are we becoming?

doi: $10.1057 /$ palgrave.fr. 9400233 